\title{
Durasi menyusu dan kejadian overweight pada remaja
}

\section{Breastfeeding duration and overweight incidence among adolescents}

Nurlaili Ramli', Madarina Julia², Toto Sudargo ${ }^{3}$

\begin{abstract}
Background: Statistic showed an increasing number of overweight incidences among children in Aceh Province. However, relationship between breastfeeding and risk of overweight and obesity is still controversial due to strong confounding factors. Hence, the relationship between breastfeeding and obesity is unclear. To reduce the confounding factors, siblings analysis can be undertaken as children live in the same environment.

Objective: To investigate the influence of siblings overweight status on breastfeeding duration and overweight incidence among adolescents and to explore other environmental and genetic factors related to overweight incidence in adolescents.

Method: This was an observational-analytical study with a matched case control design. There were 50 subjects for each group. Subjects in the case group were taken from existing cases, while the control group was selected by purposive sampling by matching in age and gender. Paired t test, McNemar test and conditional logistic regression were performed to analyse the data.

Result: Overweight adolescents have shorter breastfeeding duration than non-overweight adolescents. Multiple conditional logistic regression tests on overweight status in siblings showed that breastfeeding duration could reduce overweight incidence among adolescents (OR=0.81; 95\% Cl:0.69-0.96).

Conclusion: Overweight adolescents have shorter duration of breastfeeding than those who were not overweight. Factors that affect the risk of overweight among adolescents in this study were mother's education, adolescent's eating behavior, mother's overweight status and sibling's overweight status.
\end{abstract}

KEY WORDS: breastfeeding duration, overweight, adolescents, siblings

\section{ABSTRAK}

Latar belakang: Data statistik menunjukkan adanya peningkatan jumlah anak dengan overweight di Provinsi Aceh. Hubungan antara durasi menyusu dengan risiko overweight dan obesitas masih kontroversial karena adanya faktor perancu yang kuat sehingga hubungan antara durasi menyusu dan obesitas masih belum jelas. Faktor perancu dikurangi dengan melakukan analisis pada saudara kandung karena anak tinggal dalam lingkungan yang sama.

Tujuan: Mengetahui pengaruh status overweight saudara kandung terhadap durasi menyusu dan kejadian overweight pada remaja serta faktor lain yang berhubungan dengan kejadian overweight pada remaja dari faktor lingkungan dan genetik.

Metode: Desain penelitian analitik observasional dengan rancangan matched case control. Subjek penelitian untuk kelompok kasus dan kontrol masing-masing berjumlah 50 orang yang memenuhi kriteria inklusi dan eksklusi. Teknik pemilihan sampel untuk kelompok kasus dengan mengambil kasus yang ada sedangkan kelompok kontrol secara purposive sampling dengan melakukan matching pada umur dan jenis kelamin. Data dianalisis dengan menggunakan paired t-test, McNemar test, dan kondisional regresi logistik.

Hasil: Remaja yang overweight mempunyai durasi menyusu yang lebih pendek dibandingkan remaja yang tidak overweight. Hasil analisis multiple conditional regresi logistik terhadap status overweight pada saudara kandung, ketika dianalisis secara bersamaan menunjukkan bahwa durasi menyusu dapat menurunkan kejadian overweight pada remaja (OR=0,81; 95\% Cl:0,69-0,96).

Simpulan: Remaja yang mengalami overweight mempunyai durasi menyusu yang lebih pendek dibandingkan remaja yang tidak overweight. Faktor yang dapat mempengaruhi risiko overweight pada remaja adalah pendidikan ibu, perilaku makan remaja serta status overweight ibu dan saudara kandung.

KATA KUNCI: durasi menyusu, overweight, remaja, saudara kandung

\section{PENDAHULUAN}

Kegemukan (overweight) dan obesitas telah menjadi epidemi global bukan hanya di negara maju namun juga di negara berkembang terutama di daerah perkotaan (1). Indonesia dan Provinsi Aceh pada tahun 2010 memiliki jumlah anak usia 6-12 tahun yang mengalami overweight sebesar $9,2 \%$ dan $11,6 \%$ sedangkan jumlahnya pada

\footnotetext{
Korespondensi: Jurusan Kebidanan Politeknik Kesehatan Kementerian Kesehatan Aceh, Jl. Dr. T. Syarief Thayeb Lampriet, Banda Aceh, e-mail: nurlaili.ramli@yahoo.com

${ }^{2}$ Bagian IImu Kesehatan Anak Rumah Sakit Umum Pusat Dr. Sardjito/ Fakultas Kedokteran Universitas Gadjah Mada, Jl. Kesehatan No 1, Yogyakarta, e-mail: madarinajulia@yahoo.com

3.Program Studi Gizi Kesehatan, Fakultas Kedokteran Universitas Gadjah Mada, Jl. Farmako, Sekip Utara, Yogyakarta 55281, e-mail: toto_sudargo@yahoo.co.id
} 
anak yang berusia 13-15 tahun sebanyak 2,5\% dan $2,4 \%$. Prevalensi anak overweight di Provinsi Aceh telah mengalami peningkatan dari 4,2\% tahun 2007 menjadi 6,55\% pada tahun 2008 (2). Secara nasional, prevalensi overweight pada anak laki-laki lebih tinggi dibandingkan anak perempuan yaitu sebesar $10,7 \%$ dibandingkan $7,7 \%$ pada anak usia 6-12 tahun serta 2,9\% dibandingkan $2 \%$ pada anak usia 13-15 tahun. Prevalensi overweight di perkotaan lebih tinggi $(10,4 \%)$ dibandingkan dengan di pedesaan $(8,1 \%)(3)$.

Praktik lamanya pemberian ASI pada anak balita di Indonesia rata-rata adalah 20,7 bulan sedangkan di Provinsi Aceh adalah sebesar 19,7 bulan dan median pemberian ASI eksklusif adalah 0,6 bulan (4). Demikian juga dengan pelaksanaan pemberian ASI dan pemberian awal makanan pada bayi di Provinsi Aceh masih belum sesuai dengan harapan yaitu pemberian ASI eksklusif hanya sebesar 11,9\% (5).

Pencegahan terjadinya overweight pada masa bayi sangat penting untuk menghindari timbulnya penyakit kronis di masa datang. Pemberian air susu ibu (ASI) merupakan salah satu faktor yang dapat mencegah terjadinya obesitas pada anak dan remaja (6-11). Namun, hubungan pemberian ASI dalam mencegah overweight dan obesitas masih diperdebatkan.

Penelitian yang melibatkan saudara kandung dalam analisis data diharapkan dapat memberikan penjelasan lebih baik mengenai hubungan menyusu dan kelebihan berat badan dari faktor lingkungan dan genetik (11). Penelitian terhadap anak berusia 9-19 tahun di Amerika Serikat menunjukkan bahwa anak yang mendapatkan ASI mempunyai body mass index (BMI) lebih rendah pada saat remaja daripada saudara kandungnya yang tidak mendapatkan ASI (12). Penelitian lain pada remaja berusia 9-14 tahun di Amerika Serikat menunjukkan bahwa overweight akan terjadi pada saudara kandung yang mempunyai durasi menyusu lebih lama 0,92 kali bila dibandingkan saudara kandung yang mempunyai durasi menyusu lebih pendek (13). Sebaliknya, penelitian kohort yang melakukan analisis terhadap saudara kandung, tidak memperlihatkan bukti adanya efek perlindungan pemberian ASI terhadap peningkatan berat badan (14).

Tujuan penelitian ini adalah untuk mengetahui pengaruh durasi menyusu dan kejadian overweight pada remaja serta untuk mengetahui faktor lain yang berhubungan dengan kejadian overweight pada remaja seperti status sosial ekonomi, pendidikan orang tua, perilaku makan remaja, serta status overweight saudara kandung dan orang tua.

\section{BAHAN DAN METODE}

Penelitian dilaksanakan di Sekolah Menengah Pertama (SMP) Negeri 2 Kota Banda Aceh, Provinsi
Aceh dari tanggal 5 Agustus 2010 sampai dengan 10 Desember 2010. Subjek penelitian adalah anak laki-laki dan perempuan kelas 1-3 SMP yang dapat diukur tinggi badan dan berat badannya pada saat penelitian dilakukan. Kriteria eksklusi adalah anak yang mempunyai orang tua tunggal, tidak mempunyai saudara kandung yang berusia remaja, dan pada saat pengumpulan data sedang sakit atau menderita penyakit infeksi (diare, batuk, pilek, dll). Penelitian ini dilaksanakan setelah mendapatkan surat kelaikan etik penelitian dari Komite Etik Penelitian Biomedis pada manusia Fakultas Kedokteran Universitas Gadjah Mada Yogyakarta dan mendapatkan informed consent yang telah ditandatangani oleh orang tua remaja.

Perkiraan besar sampel dalam penelitian ini dihitung dengan menggunakan software Power Analysis and Sample Size (PASS) (15) dengan tingkat kepercayaan 95\% $(\alpha=0,05)$ dan power $80 \%(\beta=0,1953)$ serta estimasi proporsi durasi menyusu sebesar 0,50 pada kelompok kasus serta pada kelompok kontrol sebesar 0,25 (16), sehingga sampel minimal untuk kelompok kasus dan kontrol masing-masing sebanyak 50 orang.

Pengambilan sampel dimulai dengan melakukan skrining terhadap 644 siswa SMP kelas 1-3 yang diukur berat badan dan tinggi badannya. Overweight pada remaja dan saudara kandung ditentukan melalui pengukuran indeks massa tubuh (IMT) per umur (U) (IMT/U atau berat badan dibagi kuadran tinggi badan per umur). Hasil pengukuran diklasifikasikan berdasarkan standar World Health Organization (WHO) (17) tentang status gizi anak usia 5-19 tahun menggunakan software WHO AntroPlus, dengan cut off point lebih dari atau sama dengan $+2 S D$ dikategorikan menjadi overweight dan kurang dari +2SD dikategorikan tidak overweight. Berdasarkan hasil pengukuran diperoleh remaja yang mengalami overweight berjumlah 60 siswa namun yang memenuhi kriteria inklusi dan eksklusi berjumlah 50 orang remaja overweight dan 50 orang remaja yang tidak overweight. Pemilihan subjek penelitian dilakukan secara berpasangan pada kelompok kasus (overweight) dan kontrol (normal) dengan melakukan matching terhadap umur dan jenis kelamin. Jumlah remaja perempuan 19 pasang dan laki-laki 31 pasang.

Data durasi menyusu, perilaku makan, status sosial ekonomi, dan pendidikan orang tua diperoleh dengan menggunakan kuesioner yang diisi oleh remaja dan orang tua. Durasi menyusu adalah lamanya pemberian ASI ketika masa bayi (bulan) hingga usia 2 tahun atau lebih berdasarkan pengakuan orang tua. Perilaku makan diukur menggunakan kuesioner berupa pertanyaan tertutup berjumlah 35 pernyataan. Skor penilaian berdasarkan nilai cut off point yang dihitung dengan kurva receiver operating characteristic (ROC) dengan kritera tidak baik bila skor kurang dari 66 dan baik bila skor lebih dari atau sama dengan 66 . Hasil pengukuran IMT atau BMI (berat badan/tinggi badan²) orang tua dikategorikan berdasarkan standar WHO (18) yaitu 
Tabel 1. Analisis bivariat dengan conditional logistic regression

\begin{tabular}{|c|c|c|c|c|c|}
\hline Variabel & $\begin{array}{c}\text { Kasus } \\
\mathrm{n}=50(\%)\end{array}$ & $\begin{array}{c}\text { Kontrol } \\
\mathrm{n}=50(\%)\end{array}$ & OR & $95 \% \mathrm{Cl}$ & p \\
\hline $\begin{array}{l}\text { Pendidikan ayah } \\
\text { Rendah } \\
\text { Tinggi }\end{array}$ & $\begin{array}{c}2(4) \\
48(96)\end{array}$ & $\begin{array}{c}4(8) \\
46(92)\end{array}$ & 0,5 & $0,09-2,73$ & 0,420 \\
\hline $\begin{array}{l}\text { Pendidikan ibu } \\
\text { Rendah } \\
\text { Tinggi }\end{array}$ & $\begin{array}{l}29(58) \\
21(42)\end{array}$ & $\begin{array}{l}11(22) \\
39(78)\end{array}$ & 3,0 & $1,41-6,38$ & $0,004^{*}$ \\
\hline $\begin{array}{l}\text { Perilaku makan } \\
\text { Tidak baik } \\
\text { Baik }\end{array}$ & $\begin{array}{l}35(70) \\
15(30)\end{array}$ & $\begin{array}{l}10(34) \\
40(66)\end{array}$ & 3,0 & $1,41-6,38$ & $0,004^{*}$ \\
\hline $\begin{array}{l}\text { Status overweight saudara kandung } \\
\text { Overweight } \\
\text { Tidak overweight }\end{array}$ & $\begin{array}{l}27(54) \\
23(46)\end{array}$ & $\begin{array}{l}10(20) \\
40(80)\end{array}$ & 3,1 & $1,41-6,93$ & $0,010^{*}$ \\
\hline $\begin{array}{l}\text { Status overweight ayah } \\
\text { Overweight } \\
\text { Tidak overweight }\end{array}$ & $\begin{array}{l}37(74) \\
13(26)\end{array}$ & $\begin{array}{l}31(62) \\
19(38)\end{array}$ & 1,6 & $0,73-3,53$ & 0,240 \\
\hline $\begin{array}{l}\text { Status overweight ibu } \\
\text { Overweight } \\
\text { Tidak overweight }\end{array}$ & $\begin{array}{c}41(82) \\
9(18)\end{array}$ & $\begin{array}{l}31(62) \\
19(38)\end{array}$ & 3,5 & $1,15-10,63$ & $0,030^{*}$ \\
\hline
\end{tabular}

Keterangan: $\mathrm{OR}=$ Odd Rasio; $\mathrm{Cl}=$ Confidence Interval; ${ }^{*}$ bermakna $(p<0,05) ; n=$ jumlah subjek penelitian

tidak overweight jika BMI orang tua antara 18,5-22,9 dan overweight jika BMI orang tua lebih dari atau sama dengan 23. Berat badan saudara kandung dan orang tua diukur menggunakan timbangan digital dengan tingkat ketelitian 0,1 $\mathrm{kg}$ yang sudah distandarisasi. Tinggi badan diperoleh melalui pengukuran menggunakan microtoise dengan kapasitas 200 $\mathrm{cm}$ dan tingkat ketelitian $0,1 \mathrm{~cm}$ (19).

Status sosial ekonomi diukur berdasarkan pengeluaran rata-rata keluarga dalam satu bulan (20) dengan kategori tinggi bila pengeluaran per bulan tiap orang lebih dari $40 \mathrm{~kg}$ beras atau lebih dari Rp 240.000 dan rendah jika pengeluaran per bulan tiap orang kurang dari atau sama dengan $40 \mathrm{~kg}$ beras atau kurang dari atau sama dengan Rp 240.000. Pendidikan orang tua dikategorikan tinggi jika pernah atau tamat SMA atau PT sedangkan rendah jika orang tua pernah atau tamat SD, SLTP atau sederajat.

Analisis bivariat untuk mengetahui hubungan antara durasi menyusu dan variabel perancu menggunakan conditional logistic regression. Paired t-test digunakan untuk mengetahui perbedaan rata-rata antara variabel durasi menyusu dan kejadian overweight pada remaja sedangkan variabel perancu (counfonding) terhadap durasi menyusu diuji menggunakan independent $t$-test $(21,22)$. Analisis bivariat untuk mengetahui hubungan antara variabel perancu dan variabel terikat menggunakan $\mathrm{McNemar}$ test $(23,24)$. Analisis multivariat menggunakan conditional logistic regression dengan pemodelan tertentu untuk mengetahui hubungan antara variabel bebas dan terikat dengan mengontrol pengaruh sejumlah variabel perancu. Analisis yang digunakan dengan tingkat kemaknaan $(p)$ kurang dari 0,05 dan interval kepercayaan $95 \%$ (24). Analisis dilakukan menggunakan program software stata.

\section{HASIL}

Hasil penelitian menunjukkan usia remaja berkisar 11,3-14,6 tahun dan jumlah saudara dalam kelompok kasus dan kontrol berkisar 2-7 orang. Remaja yang lebih tua usianya dari saudara kandungnya sebesar 30 orang (60\%) pada kelompok kasus dan 24 orang (48\%) pada kelompok kontrol. Seluruh subjek penelitian termasuk dalam kategori status sosial ekonomi tinggi (100\%). Hasil penelitian menunjukkan bahwa $53-81 \%$ remaja mempunyai perilaku makan tidak baik seperti makan tidak teratur, tidak minum jus, jarang makan malam dan sarapan, tidak suka makan sayur dan ikan serta lebih suka jajan daripada makan nasi. Tabel 1 menunjukkan adanya perbedaan bermakna antara remaja yang mengalami overweight dan remaja yang tidak overweight $(p<0,05)$ pada pendidikan ibu, perilaku makan, status overweight saudara kandung, dan status overweight ibu.

Tabel 2 menunjukkan bahwa remaja yang mengalami overweight mempunyai durasi menyusu lebih pendek dibandingkan remaja yang tidak overweight. Rata-rata BMI z-score saudara kandung dan BMl ibu lebih tinggi pada remaja yang overweight dibandingkan yang tidak overweight.

Hasil analisis McNemar menunjukkan bahwa pendidikan ibu yang rendah dan perilaku makan tidak baik berisiko 3 kali meningkatkan kejadian overweight pada remaja. Saudara kandung yang overweight berisiko 3,1 kali dan ibu yang overweight berisiko 3,5 kali meningkatkan kejadian overweight pada remaja (Tabel 3). Hasil analisis dengan conditional logistic regression dan McNemar menunjukkan bahwa variabel pendidikan ibu, perilaku makan, status overweight pada saudara kandung dan 
Tabel 2. Analisis paired t-test durasi menyusu pada remaja dan saudara kandung, usia saudara kandung, BMI z- score saudara kandung dan orang tua terhadap kejadian overweight pada remaja

\begin{tabular}{|c|c|c|c|c|}
\hline \multirow[t]{2}{*}{ Variabel } & $\begin{array}{c}\text { Kasus } \\
\text { (Overweight) }\end{array}$ & $\begin{array}{c}\text { Kontrol } \\
\text { (Tidak overweight) }\end{array}$ & $95 \% \mathrm{Cl}$ & $\mathbf{p}$ \\
\hline & Mean $\pm S D$ & Mean $\pm S D$ & & \\
\hline Durasi menyusu (bulan) & $12,9 \pm 5,2$ & $16,0 \pm 3,6$ & $-4,76--1,40$ & $0,001^{*}$ \\
\hline BMI z-score saudara kandung & $1,3 \pm 1,0$ & $0,3 \pm 1,4$ & $0,54-1,61$ & $0,001^{*}$ \\
\hline Usia saudara kandung (tahun) & $12,9 \pm 3,1$ & $13,7 \pm 3,3$ & $-2,11-0,49$ & 0,11 \\
\hline BMI ayah $\left(\mathrm{kg} / \mathrm{m}^{2}\right)$ & $24,5 \pm 2,1$ & $23,6 \pm 2,5$ & $-0,01-1,82$ & 0,05 \\
\hline BMl ibu $\left(\mathrm{kg} / \mathrm{m}^{2}\right)$ & $26,2 \pm 3,3$ & $24,4 \pm 2,9$ & $0,43-3,09$ & $0,01^{*}$ \\
\hline
\end{tabular}

Keterangan: $\mathrm{Cl}=$ Confidence Interval; $\mathrm{SD}=$ standar deviasi; * bermakna $(p<0,05)$

Tabel 3. Analisis McNemar variabel confounding pada remaja yang overweight (kasus) dan remaja yang tidak overweight (kontrol) terhadap kejadian overweight pada remaja

\begin{tabular}{|c|c|c|c|c|c|c|c|}
\hline \multirow{3}{*}{$\begin{array}{r}\text { Kasus } \\
\text { Pendidikan ayah }\end{array}$} & \multirow{2}{*}{\multicolumn{2}{|c|}{$\begin{array}{c}\text { Kontrol } \\
\text { Pendidikan ayah }\end{array}$}} & \multirow{3}{*}{$\begin{array}{c}\% \\
\text { Diskordan }\end{array}$} & \multirow{3}{*}{ OR } & \multirow{3}{*}{$95 \% \mathrm{Cl}$} & \multirow{3}{*}{$\mathrm{X}^{2}$} & \multirow{3}{*}{$\mathbf{p}$} \\
\hline & & & & & & & \\
\hline & Rendah & Tinggi & & & & & \\
\hline Rendah (SD\&SMP) & 0 & 2 & 12 & 0,5 & $0,05-3,49$ & 0,7 & 0,690 \\
\hline Tinggi (SMA\&PT) & 4 & 44 & & & & & \\
\hline \multirow{2}{*}{ Pendidikan ibu } & \multicolumn{2}{|c|}{ Pendidikan ibu } & & & & & \\
\hline & Rendah & Tinggi & & & & & \\
\hline Rendah (SD\&SMP) & 2 & 27 & 72 & 3,0 & $1,37-7,25$ & 9 & 0,004 \\
\hline Tinggi (SMA\&PT) & 9 & 12 & & & & & \\
\hline \multirow{2}{*}{ Perilaku makan } & \multicolumn{2}{|c|}{ Perilaku makan } & & & & & \\
\hline & Tidak baik & Baik & & & & & \\
\hline Tidak baik & 8 & 27 & 72 & 3,0 & $1,37-7,25$ & 9 & 0,004 \\
\hline Baik & 9 & 6 & & & & & \\
\hline \multirow{2}{*}{$\begin{array}{l}\text { Status overweight saudara } \\
\text { kandung }\end{array}$} & \multicolumn{2}{|c|}{ Status overweight saudara kandung } & & & & & \\
\hline & Overweight & Tidak Overweight & & & & & \\
\hline Overweight & 2 & 25 & 66 & 3,1 & $1,37-8,02$ & 8,8 & 0,010 \\
\hline Tidak overweight & 8 & 15 & & & & & \\
\hline \multirow{2}{*}{ Status overweight ayah } & \multicolumn{2}{|c|}{ Status overweight ayah } & & & & & \\
\hline & Overweight & Tidak overweight & & & & & \\
\hline Overweight & 21 & 16 & 52 & 1,6 & $0,68-3,94$ & 1,4 & 0,340 \\
\hline Tidak overweight & 10 & 3 & & & & & \\
\hline \multirow{2}{*}{ Status overweight ibu } & \multicolumn{2}{|c|}{ Status overweight ibu } & & & & & \\
\hline & Overweight & Tidak overweight & & & & & \\
\hline Overweight & 27 & 14 & 36 & 3,5 & $1,09-14,60$ & 5,6 & 0,030 \\
\hline Tidak overweight & 4 & 5 & & & & & \\
\hline
\end{tabular}

ibu bermakna terhadap kejadian overweight pada remaja $(p<0,05)$. Hasil analisis independent $t$-tes pada Tabel 4 menunjukkan bahwa tidak terdapat perbedaan yang bermakna antara variabel pendidikan orang tua, perilaku makan, status overweight saudara kandung dan orang tua dengan durasi menyusu.

Hasil analisis multivariat pada Tabel $\mathbf{5}$ menunjukkan bahwa durasi menyusu tidak konsisten menurunkan kejadian overweight pada remaja ketika dilakukan kontrol pada variabel perancu. Namun, secara praktis tetap konsisten dalam menurunkan kejadian overweight pada remaja. Hasil analisis model pada multiple conditional logistic regression, model 7 sebagai model yang lebih efektif dalam menjelaskan faktor-faktor yang berkontribusi terhadap kejadian overweight pada remaja. Model ini dipilih karena semua variabel yang diikutkan dalam model adalah bermakna dan parsimoni (hemat) terhadap kejadian overweight pada remaja. Sedangkan model 10 menunjukkan bahwa durasi menyusu tidak menurunkan kejadian overweight pada remaja ketika dianalisis bersama dengan variabel pendidikan, status overweight orang tua, status overweight saudara kandung, dan perilaku makan remaja.

\section{BAHASAN}

Durasi menyusu dan status overweight pada saudara kandung yang dianalisis secara bersamaan menunjukkan bahwa durasi menyusu dapat menurunkan kejadian overweight pada remaja. Hasil meta analisis dan literature review $(25,26)$ menyimpulkan bahwa menyusu dapat 
Tabel 4. Analisis independent $t$-test variabel luar terhadap variabel bebas

\begin{tabular}{|c|c|c|c|}
\hline Variabel perancu & $\frac{\text { Durasi menyusu }}{\text { Mean } \pm \text { SD }}$ & $95 \% \mathrm{Cl}$ & $\mathbf{p}$ \\
\hline Pendidikan ayah & & & \multirow[b]{2}{*}{0,82} \\
\hline $\begin{array}{l}\text { Rendah (SD\&SMP) } \\
\text { Tinggi (SMA\&PT) }\end{array}$ & $\begin{array}{l}16,2 \pm 1,6 \\
14,4 \pm 4,8\end{array}$ & $-2,14-5,73$ & \\
\hline Pendidikan ibu & & & \\
\hline $\begin{array}{l}\text { Rendah (SD\&SMP) } \\
\text { Tinggi (SMA\&PT) }\end{array}$ & $\begin{array}{l}14,0 \pm 5,1 \\
14,8 \pm 4,4\end{array}$ & $-2,71-1,12$ & 0,20 \\
\hline Perilaku makan & & & \\
\hline $\begin{array}{l}\text { Tidak baik } \\
\text { Baik }\end{array}$ & $\begin{array}{l}14,1 \pm 4,8 \\
14,9 \pm 4,6\end{array}$ & $-2,63-1,11$ & 0,21 \\
\hline Status overweight saudara $\mathrm{k}$ & & & \\
\hline $\begin{array}{l}\text { Overweight } \\
\text { Tidak overweight }\end{array}$ & $\begin{array}{l}14,0 \pm 5,3 \\
14,8 \pm 4,4\end{array}$ & $-2,69-1,17$ & 0,22 \\
\hline Status overweight ayah & & & \\
\hline $\begin{array}{l}\text { Overweight } \\
\text { Tidak overweight }\end{array}$ & $\begin{array}{l}14,6 \pm 5,2 \\
14,2 \pm 3,5\end{array}$ & $-1,53-2,48$ & 0,68 \\
\hline Status overweight ibu & & & \\
\hline $\begin{array}{l}\text { Overweight } \\
\text { Tidak overweight }\end{array}$ & $\begin{array}{l}13,8 \pm 4,7 \\
16,3 \pm 4,2\end{array}$ & $-4,58--0,53$ & 0,93 \\
\hline
\end{tabular}

Keterangan: $\mathrm{SD}=$ standar deviasi; $\mathrm{Cl}=$ Confidence Interval

Tabel 5. Analisis pengaruh durasi menyusu dan kejadian overweight pada remaja dengan mengontrol variabel status overweight saudara kandung, pendidikan dan status overweight ibu, perilaku makan, dan durasi menyusu saudara kandung dengan multiple conditional logistic regression

\begin{tabular}{|c|c|c|c|c|c|c|c|c|c|c|}
\hline Variabel & $\begin{array}{l}\text { Model I } \\
\text { OR } \\
(95 \% \mathrm{Cl}) \\
\end{array}$ & $\begin{array}{l}\text { Model II } \\
\text { OR } \\
(95 \% \mathrm{Cl}) \\
\end{array}$ & $\begin{array}{c}\text { Model III } \\
\text { OR } \\
(95 \% \mathrm{Cl}) \\
\end{array}$ & $\begin{array}{l}\text { Model IV } \\
\text { OR } \\
(95 \% \mathrm{Cl}) \\
\end{array}$ & $\begin{array}{l}\text { Model V } \\
\text { OR } \\
95 \% \mathrm{Cl} \\
\end{array}$ & $\begin{array}{l}\text { Model VI } \\
\text { OR } \\
(95 \% \mathrm{Cl}) \\
\end{array}$ & $\begin{array}{c}\text { Model VII } \\
\text { OR } \\
(95 \% \mathrm{Cl}) \\
\end{array}$ & $\begin{array}{c}\text { Model VIII } \\
\text { OR } \\
(95 \% \mathrm{CI}) \\
\end{array}$ & $\begin{array}{l}\text { Model IX } \\
\text { OR } \\
(95 \% \mathrm{Cl}) \\
\end{array}$ & $\begin{array}{l}\text { Model X } \\
\text { OR } \\
(95 \% \mathrm{Cl}) \\
\end{array}$ \\
\hline $\begin{array}{l}\text { Durasi menyusu } \\
\text { remaja }\end{array}$ & $\begin{array}{c}0,82^{*} \\
0,72-0,94\end{array}$ & $\begin{array}{c}0,81^{*} \\
0,69-0,95\end{array}$ & $\begin{array}{c}0,83^{*} \\
0,71-0,97\end{array}$ & $\begin{array}{c}0,84^{*} \\
0,73-0,95\end{array}$ & $\begin{array}{c}0,83^{*} \\
0,72-0,96\end{array}$ & $\begin{array}{c}0,85^{*} \\
0,73-0,99\end{array}$ & $\begin{array}{c}0,81^{*} \\
0,69-0,96\end{array}$ & $\begin{array}{c}0,81^{*} \\
0,69-0,96\end{array}$ & $\begin{array}{c}0,83^{*} \\
0,69-0,98\end{array}$ & $\begin{array}{c}0,84 \\
0,71-1,01\end{array}$ \\
\hline $\begin{array}{l}\text { Status overweight } \\
\text { saudara kandung } \\
\text { Overweight } \\
\text { Tidak overweight }\end{array}$ & & $\begin{array}{c}3,27^{*} \\
1,29-8,23 \\
1\end{array}$ & $\begin{array}{c}3,33^{*} \\
1,29-8,61 \\
1\end{array}$ & & & & $\begin{array}{c}4,98^{*} \\
1,54-16,13 \\
1\end{array}$ & $\begin{array}{c}5,37^{*} \\
1,48-19,44 \\
1\end{array}$ & $\begin{array}{c}4,81^{*} \\
1,49-15,45 \\
1\end{array}$ & $\begin{array}{c}4,93^{*} \\
1,36-17,81 \\
1\end{array}$ \\
\hline $\begin{array}{l}\text { Status overweight ibu } \\
\text { Overweight } \\
\text { Tidak overweight }\end{array}$ & & & $\begin{array}{c}2,15 \\
0,58-7,89 \\
1\end{array}$ & & & $\begin{array}{c}3,11 \\
0,76-12,72 \\
1\end{array}$ & & & $\begin{array}{c}1,79 \\
0,36-8,79 \\
1\end{array}$ & $\begin{array}{c}2,69 \\
0,39-18,37 \\
1\end{array}$ \\
\hline $\begin{array}{l}\text { Perilaku makan } \\
\text { Tidak baik } \\
\text { Baik }\end{array}$ & & & & $\begin{array}{c}2,84^{*} \\
1,25-6,48 \\
1\end{array}$ & $\begin{array}{c}2,5^{\star} \\
1,05-5,90 \\
1\end{array}$ & & $\begin{array}{c}4,32^{*} \\
1,46-12,77 \\
1\end{array}$ & $\begin{array}{c}3,77^{*} \\
1,20-11,84 \\
1\end{array}$ & $\begin{array}{c}4,15^{\star} \\
1,38-12,43 \\
1\end{array}$ & $\begin{array}{c}3,63^{*} \\
1,11-11,87 \\
1\end{array}$ \\
\hline $\begin{array}{c}\text { Pendidikan ibu } \\
\text { Rendah } \\
\text { Tinggi }\end{array}$ & & & & & $\begin{array}{c}2,5^{\star} \\
1,06-6,03 \\
1\end{array}$ & $\begin{array}{c}3,44^{*} \\
1,35-12,77 \\
1\end{array}$ & & $\begin{array}{c}2,69 \\
0,98-7,39 \\
1\end{array}$ & & $\begin{array}{c}3,03^{*} \\
1,03-8,90 \\
1\end{array}$ \\
\hline $\begin{array}{l}\mathrm{N} \\
\mathrm{R}^{2} \\
\text { Deviance }\end{array}$ & $\begin{array}{c}100 \\
0,183 \\
56,65\end{array}$ & $\begin{array}{c}100 \\
0,290 \\
49,19\end{array}$ & $\begin{array}{c}100 \\
0,311 \\
47,77\end{array}$ & $\begin{array}{c}100 \\
0,283 \\
49,70\end{array}$ & $\begin{array}{c}100 \\
0,350 \\
45,03\end{array}$ & $\begin{array}{c}100 \\
0,325 \\
46,75\end{array}$ & $\begin{array}{c}100 \\
0,42 \\
39,87\end{array}$ & $\begin{array}{c}100 \\
0,484 \\
35,77\end{array}$ & $\begin{array}{c}100 \\
0,433 \\
39,33\end{array}$ & $\begin{array}{c}100 \\
0,50 \\
34,64\end{array}$ \\
\hline
\end{tabular}

Keterangan: $\mathrm{N}=$ jumlah total subjek penelitian; $\mathrm{R}^{2}=$ Koefisien determinan; $\mathrm{OR}=$ odd rasio; $\mathrm{Cl}=\mathrm{Confidence} \mathrm{Interval;}{ }^{*}$ bermakna $(\mathrm{p}<0,05)$

menurunkan kejadian overweight pada anak dan remaja walaupun efek tersebut kecil. Hasil analisis paired t-test menunjukkan bahwa remaja yang mengalami overweight mempunyai durasi menyusu lebih pendek dibanding remaja yang tidak overweight. Setiap peningkatan 1 bulan durasi menyusu, kemungkinan dapat menurunkan risiko overweight pada remaja sebesar $18,3 \%$.
Penelitian di Jerman yang mendukung hasil penelitian ini menyimpulkan bahwa setiap penambahan 1 bulan pemberian ASI, kemungkinan menurunkan kejadian overweight sebesar $4 \%$ pada anak (25) dan prevalensi overweight lebih tinggi pada remaja yang tidak menyusu dibanding remaja yang menyusu $(27,28)$. Hasil penelitian di Massachusetts menyatakan adanya efek protektif 
pemberian ASI yaitu durasi pemberian ASI yang lebih lama dapat dikaitkan dengan kemungkinan overweight yang lebih rendah. Peningkatan durasi menyusu hingga 3,7 bulan dapat menurunkan kejadian overweight pada anak sebesar $6-8 \%$ (13). Namun, hasil penelitian ini berbeda dengan penelitian di Brisbane pada remaja usia 14-21 tahun yang disebabkan peneliti melakukan observasi langsung terhadap berat badan dan tinggi badan subjek serta adanya perbedaan dalam klasifikasi durasi menyusu $(16,29)$. Recall bias dapat terjadi pada orang tua dalam mengingat durasi menyusu dan perbedaan klasifikasi durasi menyusu juga merupakan penyebab terjadinya penemuan yang berbeda.

Beberapa mekanisme biologis yang dapat menjelaskan efek perlindungan durasi menyusu terhadap kejadian overweight pada remaja yaitu mekanisme perilaku, hormonal, dan perbedaan asupan makronutrien. Bayi yang diberikan ASI dapat mengatur rasa lapar dan kenyang, mekanisme ini dapat menetap hingga waktu lama (30). ASI juga mengandung leptin yang dapat mengatur nafsu makan dan keseimbangan energi, hal ini merupakan salah satu faktor yang dapat melindungi dari terjadinya overweight pada anak (31). Konsumsi protein berlebihan pada anak yang diberikan susu formula dapat merangsang sekresi insulin dan hormon pertumbuhan yang lebih tinggi dibandingkan pada anak yang diberi ASI. Hal ini dapat meningkatkan aktivitas sel lemak yang berdampak pada peningkatan risiko overweight dikemudian hari (30).

Berdasarkan hasil pemodelan, durasi menyusu tidak menurunkan kejadian overweight pada remaja ketika dianalisis bersama dengan variabel perancu. Hal ini dapat terjadi karena jumlah sampel penelitian yang sedikit sehingga menyebabkan hasil penelitian tidak konsisten bermakna. Namun, secara praktis tetap konsisten dalam menurunkan kejadian overweight pada remaja. Penelitian ini juga sesuai dengan hasil penelitian lain di Inggris dan Australia yang menyatakan terdapat hubungan yang tidak konsisten antara durasi menyusu dan kejadian overweight pada remaja ketika diikutkan variabel perancu dalam analisis secara keseluruhan $(16,29)$. Hubungan durasi menyusu dan overweight pada anak dipengaruhi oleh faktor-faktor lain yaitu gaya hidup, berat badan ibu, dan faktor sosial $(29,32)$. Interaksi antara faktor lingkungan dan genetika juga merupakan penyebab terjadinya obesitas (33).

Selain faktor genetik dan lingkungan, gaya hidup, sosial ekonomi, dan pendidikan orang tua yang rendah juga berperan terhadap kejadian overweight pada remaja $(29,32,34-37)$. Status sosial ekonomi berhubungan dengan risiko overweight dan obesitas pada anak dan remaja walaupun berbeda-beda di setiap negara. Risiko overweight lebih tinggi terjadi pada keluarga dengan status sosial ekonomi tinggi di India dan Cina dibandingkan pada keluarga dengan status sosial ekonomi rendah $(38,39)$. Sementara itu, penelitian yang dilakukan di Brazil menunjukkan bahwa menyusu hanya berpengaruh terhadap kejadian overweight pada keluarga dengan status sosial ekonomi rendah (6).

Hasil penelitian ini menunjukkan bahwa risiko overweight pada remaja tidak berhubungan dengan status sosial ekonomi yang tinggi. Di negara maju, keluarga dengan status sosial ekonomi tinggi lebih memperhatikan diit anak dan pencegahan obesitas dibandingkan pada keluarga dengan sosial ekonomi yang rendah sedangkan hubungan antara status ekonomi yang rendah terhadap kejadian overweight dapat diakibatkan oleh variasi dan jumlah anggota keluarga yang sedikit. Demikian juga anak dengan orang tua tunggal dan riwayat keluarga obesitas, akan mempertahankan berat badan ideal terutama jika akses terhadap makanan sehat kurang akibat sosial ekonomi yang rendah (37,40-42).

Masyarakat yang berpenghasilan tinggi di negara berkembang cenderung berisiko terhadap kejadian overweight pada remaja. Hal ini disebabkan oleh perilaku makan yang tinggi karbohidrat dan lemak serta kurang melakukan aktivitas fisik $(34,43)$. Perubahan gaya hidup mempengaruhi pola aktivitas fisik anak dan remaja, mereka lebih banyak melakukan aktivitas sambil duduk misalnya menonton sambil makan makanan ringan, bermain game, dan tidak melakukan kegiatan fisik yang cukup sehingga meningkatkan kejadian overweight (44).

Hasil analisis bivariat menunjukkan hanya 4 variabel yang terbukti berhubungan bermakna dengan kejadian overweight pada remaja yaitu pendidikan ibu, status overweight ibu, perilaku makan, dan status overweight saudara kandung. Penelitian ini menunjukkan bahwa pendidikan ibu yang rendah dapat meningkatkan risiko overweight pada remaja. Hal ini dapat terjadi karena ibu kurang paham tentang kebiasaan mengonsumsi makanan yang sehat dan bergizi. Hal tersebut didukung oleh penelitian di Cina yang menyatakan bahwa ibu dengan pendidikan rendah berisiko 1,86 kali meningkatkan kejadian overweight pada anak (45). Pendidikan ibu yang rendah juga terbukti meningkatkan kejadian overweight pada anak di Korea terutama pada keluarga yang berpenghasilan rendah (37). Rendahnya tingkat pendidikan ibu dapat meningkatkan risiko kejadian overweight dan sebaliknya peningkatan pendidikan ibu dapat menurunkan risiko anak mengalami overweight (46).

Hasil penelitian menunjukkan bahwa status overweight ibu dapat meningkatkan risiko kejadian overweight pada remaja sebesar 3,5 kali. Penelitian kasus kontrol yang dilakukan di Brazil juga menyimpulkan hasil yang sama, bahwa anak yang mempunyai ibu dengan BMl lebih dari atau sama dengan 30 memiliki kemungkinan 2 kali lebih besar untuk mengalami overweight dibandingkan anak yang ibunya tidak overweight (47). Faktor genetika diketahui merupakan salah satu penyebab terjadinya obesitas pada anak. Anak akan cenderung mengalami overweight jika orang tua juga mengalami overweight, terutama jika ibu yang mengalami 
overweight. Hal ini terjadi karena selain gen yang diturunkan dari ibu, seorang ibu memegang peranan penting dalam perilaku dan pola makan remaja (48).

Sebesar 53-81\% perilaku makan remaja tergolong tidak baik. Perilaku makan merupakan salah satu faktor yang juga dapat mempengaruhi kejadian overweight pada remaja. Penelitian ini juga mendukung penelitian yang menyatakan bahwa perilaku makan yang tidak baik seperti mengonsumsi junk food, makanan manis, dan sering makan makanan selingan dapat meningkatkan prevalensi overweight pada anak sekolah menengah atas (SMA) di India (49). Anak yang makan terlalu banyak (overeat) akan berisiko mengalami overweight dibandingkan anak yang pemilih dalam jenis makanan (50). Perilaku makan pagi serta mengonsumsi buah dan sayuran secara teratur akan mengurangi risiko overweight pada remaja (51).

Hasil penelitian menunjukkan bahwa saudara kandung yang mengalami overweight akan meningkatkan kejadian overweight pada remaja. Penelitian ini didukung oleh penelitian di Kuwait yang menyatakan bahwa saudara kandung yang mengalami obesitas berhubungan dengan kejadian overweight pada saudaranya (45). Hal ini dapat terjadi karena faktor genetik dan lingkungan yang sama (52).

Besarnya pengaruh ASI dan durasi menyusu dibuktikan oleh penelitian di Amerika Serikat yang menggunakan model efek tetap pada saudara kandung (sibling-fixed effect). Penelitian tersebut menunjukkan bahwa anak yang mendapatkan ASI mempunyai BMI lebih rendah pada saat remaja dibandingkan saudara kandungnya yang tidak mendapat ASI (12). Hasil yang berbeda ditunjukkan pada penelitian lain di Amerika Serikat yang membandingkan hasil temuan dari sebuah rancangan kohort klasik dengan rancangan sibling (saudara kandung). Analisis terhadap saudara kandung tidak memperlihatkan bukti adanya efek pelindung pemberian ASI terhadap kejadian overweight (14). Hal ini dikaitkan dengan karakteristik ibu yang tidak diamati yaitu karakteristik yang berkaitan dengan pilihan ibu untuk memberi ASI atau tidak dan perkembangan status berat badan anak.

Kejadian overweight pada remaja dapat dicegah dengan pemberian ASI hingga usia 2 tahun. Namun, durasi menyusu bukan satu-satunya faktor yang berpengaruh terhadap kejadian overweight pada remaja. Faktor genetik dan lingkungan termasuk perilaku makan tetap menjadi faktor yang juga berperan terhadap kejadian overweight pada remaja.

\section{SIMPULAN DAN SARAN}

Remaja yang overweight mempunyai durasi menyusu yang lebih pendek dibandingkan remaja yang tidak overweight. Beberapa faktor yang secara terpisah dapat mempengaruhi risiko overweight pada remaja adalah pendidikan ibu, perilaku makan remaja serta status overweight ibu dan saudara kandung. Para tenaga kesehatan diharapkan dapat meningkatkan pemberian informasi tentang manfaat durasi menyusui pada masyarakat yang salah satunya berguna untuk menurunkan kejadian overweight pada remaja.

\section{RUJUKAN}

1. WHO. Fact sheet: obesity and overweight. Geneva: WHO Press Office; 2006.

2. Dinkes Provinsi NAD. Pemantauan status gizi. Banda Aceh: Dinkes Provinsi NAD; 2008.

3. Kemenkes RI. Riset kesehatan dasar (Riskesdas) 2010. Jakarta: Badan Penelitian dan Pengembangan Kesehatan Departemen Kesehatan Republik Indonesia; 2010.

4. BPS, Macro International. Survei demografi kesehatan Indonesia. Calverton, Maryland, USA: Macro International; 2007.

5. Dinas Kesehatan Aceh. Profil kesehatan Aceh tahun 2011. Banda Aceh: Dinas Kesehatan Aceh; 2012.

6. Araujo C, Victoria C, Hallal P, Gigante D. Breastfeeding and overweight in childhood: evidence from the Pelotas 1993 birth cohort study. Int J Obes 2006;30:500-6.

7. Semba RD. Handbook of nutrition and ophthalmology. New Jersey: Humana Pres; 2007.

8. WHO. Obesity and overweight. Geneva: World Health Organization; 2006.

9. Strawn LMG, Mei Z. Does breastfeeding protect against pediatric overweight? analysis of longitudinal data from the Centers for Disease Control and Prevention Pediatric Nutrition Surveillance System. Pediatrics 2004;113(2):e81-6.

10. Procter SB, Holcomb CA. Breastfeeding duration and childhood overweight among low income children in Kansas, 1998-2002. Am J Public Health 2008;98(1):106-10.

11. Cope MB, Allison DB. Critical review of the World Health Organization's (WHO) 2007 report on 'evidence of the long-term effects of breastfeeding: systematic reviews and meta-analysis with respect to obesity. Obes Rev 2008;9:594-605.

12. Metzger MW, Mc.Dade TW. Breastfeeding as obesity prevention in the united states: a sibling difference model. Am J Hum Biol 2010;22(3):291-6.

13. Gillman MW, Shiman SLR, Berkey CS, Frazier AL, Rockett HR, Camargo Jr CA, Field AE, Colditz GA. Breastfeeding and overweight in adolescence: withinfamily analysis. Epidemiology 2006;17(1):112-4.

14. Nelson MC, Larsen PG, Adair LS. Are adolescents who were breast-fed less likely to be overweight?: analyses of sibling pairs to reduce confounding. Epidemiology 2005;16(2):247-53. 
15. Onis Md, Onyango AW, Borghi E, Siyam A, Nishida C, Siekmann J. Development of a WHO growth reference for school-aged children and adolescents. Bulletin of the World Health Organization 2007;85(9):660-67.

16. Hintze JL, NCCS. Power analysis and sample size. Kaysville: Utah; 2008.

17. Shields L, Callaghan O, Michael W, Gail M, Najman JM, Bor W. Breastfeeding and obesity at 14 years: a cohort study. J Paediatr Child Health 2006;42:289-96.

18. WHO. The Asia-Pacific perspective: redefining obesity and its treatment. Geneva: International Obesity Taskforce; 2000.

19. Gibson RS. Principless of nutrition assesment. USA: Oxford University Press; 2005.

20. Sajogjo. Garis kemiskinan dan kebutuhan minimum pangan. Bogor: LPPM Institut Pertanian Bogor; 1996.

21. Aday LA, Cornelius LJ. Designing and conducting health survey: a comprehensive guide. Third ed. San Fransisco: Jossey-Bass Pub; 2006.

22. Vittinghoff E, Shiboski SC, Glidden DV, McCulloch CE. Regression methods in biostatistics: linear, logistic, survival, and repeated measures models. Dietz K, Gail M, Krickeberg K, Samet J, Tsiatis A, editors. New York: Springer Science\&Business Media, Inc; 2005.

23. Smoller SW. Biostatistics and epidemiology: a primer for health and biomedical professionals. Third ed. New York: Springer; 2004.

24. Kleinbaum DG, Klein M. Logistic regression: a self learning text. Dietz K, Gail M, Krickeberg K, Tsiatis A, Samet J, editors. New York: Spinger; 2002.

25. Harder T, Bergmann R, Kallischnigg G, Plagemann A. Duration of breastfeeding and risk of overweight: a meta-analysis. Am J Epidemiol 2005;162(5):397403.

26. Arenz S, Ruckerl R, Koletzko B, Kries R. Breastfeeding and childhood obesity - a systematic review. Int J Obes Relat Metab Disord 2004;28(10):1247-56.

27. Fallahzadeh H, Golestan M, Rezvanian T, Ghasemian Z. Breastfeeding history and overweight in 11 to 13 year-old children in Iran. World J Pediatr 2009;5(1):3641.

28. Siquera RS, Monteiro CA. Breastfeeding and obesity in school-age children from families of high sosioeconomic status. Rev Saude Publica 2007;41(1):1-7.

29. Shields L, Mamun AA, O'Callaghan M, Williams GM, Najman JM. Breastfeeding and obesity at 21 years: a cohort study. J Clin Nurs 2010;19(11-12):1612-7.

30. Li R, Grummer-Strawn L. Racial and ethnic disparities in breastfeeding among United States infants: Third National Health and Nutrition Examination Survey (1988-1994). Birth 2002;29(4):251-7.

31. Strauss RS, Pollack HA. Epidemic increase in childhood overweight, 1986-1998. JAMA 2001;286(22):2845-8.
32. Sabanayagam C, Shankar A, Chong Y-S, Wong TY, Saw SM. Breast-feeding and overweight in Singapore school children. Pediatr Int 2009;51(5):650-6.

33. Srivastava N, Lakhan R, Mittal B. Pathophysiology and genetics of obesity. Indian J Exp Biol 2007;45:92936.

34. Antipatis VJ, Gill TP. Obesity as a global problem. In: Bjorntorp $P$, editor. International textbook of obesity. Sweden: John Wiley \& Sons,LTD; 2001.

35. WHO. Obesity: preventing and managing the global epidemic. Geneva: World Health Organization; 2000.

36. Chan RSM, Woo J. Prevention of overweight and obesity: how effective is the current public health approach. Int $\mathrm{J}$ Environ Res Public Health 2010;7(3):765-83.

37. Cho Y-G, Kang J-H, Kim K-A, Song J-H. The relationship between low maternal education level and children's overweight in the Korean society. Obes Res Clin Pract 2009;3(3):133-40.

38. Laxmaiah A, Nagalla B, Vijayaraghavan K, Nair M. Factors affecting prevalence of overweight among 12 to 17-year-old urban adolescents in Hyderabad, India. Obesity 2007;15(6):1384-90.

39. Shi Z, Lien N, Kumar BN, Dalen I, Ottesen GH. The sociodemographic correlates of nutritional status of school adolescents in Jiangsu Province, China. J Adolesc Health 2005;37(4):313-22.

40. Serra-Majem L, Aranceta BJ, Pérez-Rodrigo C, Ribas-Barba L, Delgado-Rubio A. Prevalence and deteminants of obesity in Spanish children and young people. Br J Nutr 2006;96(1):S67-72.

41. Gibson LY, Byrne SM, Davis EA, Blair E, Jacoby P, Zubrick SR. The role of family and maternal factors in childhood obesity. MJA 2007;186(11):591-5.

42. Grøholt E-K, Stigum H, Nordhagen R. Overweight and obesity among adolescents in Norway: cultural and socio-economic differences. J Public Health 2008;30(3):258-65.

43. Burton BT. Human nutrition: a textbook of nutrition in health and disease. third ed. New York: A Blakiston Publication; 1976.

44. Caballero B, Allen L, Prentice A. Encyclopedia of human nutrition. second ed. Oxford: Elsevier Academic press; 2005.

45. Jingxiong J, Rosenqvist U, Huishan W, Koletzko B. Relationship of parental characteristics and feeding practices to overweight in infants and young children in Beijing, China. Public Health Nutr 2008;12(7):973-8.

46. Kersey M, Lipton R, Rosado MS, Kumar J, This ted R, Lantos JD. Breast-feeding history and overweight in Latino preschoolers. Ambul Pediatr 2005;5(6):355-8.

47. Neutzling MB, Tadde JAA, Gigante DP. Risk factors of obesity among Brazilian adolescents: a case-control study. Public Health Nutr 2003;6(8):743-49. 
48. Chou Y-C, Pei J-S. Risk factors of adolescent obesity in Taiwan and its association with physical activity, blood pressure and waist circumference. Asian J Sports Med 2010;1(4):214-22.

49. Ramesh K. Prevalence of overweight and obesity among high school students of Thiruvananthapuram City Corporation, Kerala, India. AMJ 2010;3(10):65061.

50. Dubois L, Farmer A, Girard M, Peterson K, Tokuda FT. Problem eating behaviors related to social factors and body weight in preschool children: a longitudinal study. Int J Behav Nutr Phys Act 2007;4(9):1-10.

51. Delva J, Johnston LD, O'Malley PM. The epidemiology of overweight and related lifestyle behaviors: racial/ethnic and socioeconomic status differences among American youth. Am J Prev Med 2007;33(4S):S178-86.

52. Estourgie-van Burk GF, Bartels M, Boomsma DI, Delemarre-van de Waal HA. Body size of twins compared with siblings and the general population: from birth to late adolescence. J Pediatr 2010;156(4):586-91. 